\title{
Petroleum Oil and Gas Industry Waste Treatment; Common Practice in Indonesia
}

\section{Qomarudin Helmy ${ }^{1 *}$ and Edwan Kardena ${ }^{2}$}

${ }^{1}$ Bioscience and Biotechnology Research Center, Institut Teknologi Bandung Ganesha No. 10, Bandung, West Java, Indonesia

${ }^{2}$ Water and Wastewater Engineering Research Group, Environmental Engineering Department, Institut Teknologi Bandung, Ganesha No. 10, Bandung, West Java, Indonesia

\section{Introduction}

The demand for oil, gas, and other energy sources are growing dramatically with the worldwide energy consumption that projected to increase by 37 percent in 2035. Rising demand driven by world's population which predicted to increase by 25 percent in the next 20 years [1]. Indonesia as the fourth largest population in the world, known to its total primary energy consumption increased by more than 50 percent between 2000 and 2010. Currently, Indonesia's oil production reached nearly 860,000 barrels of oil per day [2]. Oil and gas exploration and production ( $\mathrm{E}$ and $\mathrm{P}$ ) activities aside from a necessity, are responsible for various environmental accidents around the world, e.g.: Oil spills during transportation and distribution; Waste from the $\mathrm{E}$ and $\mathrm{P}$ operations in the form of oil sludge, waste drilling fluid/mud; Waste treatment plant residue (oil separator, oil catcher, dissolved air flotation); Leakage from floating storage, tankers, storage tanks; Residue from cleaning activities; Work over wastes, well completion, treatment, and stimulation fluid; Produced water; Offshore wells drilling leakage as well as the distribution of oil spilled from the well to the tanker and from the ship to the mainland $[3,4]$. Inadequate treatment of those wastes can threaten the human health and safety as well as the environment.

\section{Waste Generation}

In order to manage the potential impacts of $\mathrm{E}$ and $\mathrm{P}$ operations upon the environment, we have to identify the activities that potentially cause environmental pollution. Common wastes associated with $\mathrm{E}$ and $\mathrm{P}$ activities are described in Table 1. Generally, there are six stage/ activities in the $\mathrm{E}$ and $\mathrm{P}$ operations, i.e.,

Seismic survey (S) - Seismic is the most important geophysical method used to locate petroleum oil as it makes possible to have subsurface imaging and predict possible oil traps/prospect of a hypothetic reservoir. The common wastes from seismic operations include domestic waste, explosive waste, and equipment maintenance waste.

Exploratory drilling (D) - Once a promising geological structure has been identified, the only way to confirm the presence of petroleum oil and gas, internal pressure of a reservoir, and approximate quantity of oil and gas in the potential reservoir or source rocks is to drill exploratory wells. The common wastes from exploratory drilling include drilling muds/fluids and cuttings, cementing waste, well completion, work over/stimulation fluids, production testing waste, process water, drilling chemical and domestic wastes.

Construction (C) - Depending to the oil and gas available in the field, processing facilities basically constituted from pipes, tanks, tubing, cables, cooling system, etc are built to treat the produced oil and gas before commercialized. The common wastes from construction include used lubricants, paints, solvents and domestic wastes.

Production $(\mathrm{P})$ - When all treatment facilities are installed, the production starts from the production wells already drilled and completed to extract the oil and gas from the reservoir. The common wastes from production activity include produced water, production chemicals, and work over waste, and sludge bottom.

Maintenance (M) - Maintenance activities are common to all stages/activities of $\mathrm{E}$ and $\mathrm{P}$ process, from vehicle repair, drilling and work over rig repair, and inspection of all equipment and infrastructure. The common wastes associated with maintenance activities include used lubricants, filters, solvents, used parts, and contaminated soil.

Abandonment (A) - The decommissioning of a production field includes permanently plugging and abandoning all wells, dismantling and demolition of all facilities and equipment, closure of the landfills and burial pits, site re-vegetation and site monitoring. The common wastes from abandoning activity include construction materials, plant equipment, oil sludge, and contaminated soil.

Amongst other waste, oily sludge (e.g. crude oil contaminated soil, bottom sludge, abandoned sludge pit, burial oil sludge) also produced water are the most abundant waste in the $\mathrm{E}$ and $\mathrm{P}$ operation to date. With its average production of 860.000 barrels oil per day, Indonesia was predicted to produce approximately 51.000 cubic meter of oil sludge annually. This quantity of waste does not include oily sludge found from existing burial site/pits from the $\mathrm{E}$ and $\mathrm{P}$ operation activity

\begin{tabular}{|c|c|c|c|c|c|c|c|}
\hline \multirow{2}{*}{ Waste } & \multicolumn{6}{|c|}{$E$ and $P$ Operation } & \multirow{2}{*}{ Constituents } \\
\hline & $\mathbf{S}$ & D & C & $\mathbf{P}$ & M & A & \\
\hline Oil spill/leaks & $x$ & $x$ & $x$ & $\mathrm{X}$ & $x$ & & Hydrocarbons, chemicals \\
\hline Contaminated soil & $x$ & $x$ & $x$ & $x$ & $x$ & $\mathrm{x}$ & $\begin{array}{l}\text { Hydrocarbons, heavy metals, } \\
\text { chemicals }\end{array}$ \\
\hline Domestic waste & $x$ & $x$ & $x$ & $\mathrm{X}$ & $x$ & $\mathrm{X}$ & $\begin{array}{c}\text { Organic, solids, oil and grease, } \\
\text { nutrients }\end{array}$ \\
\hline Waste lubricants & $x$ & $x$ & & & $x$ & & Hydrocarbons, heavy metals \\
\hline Ballast water & & & & $\mathrm{X}$ & & & Hydrocarbons, heavy metals \\
\hline Boiler blow down & & $x$ & & & $x$ & & Biocides, heavy metals, scale \\
\hline $\begin{array}{l}\text { Drilling fluids, muds } \\
\text { and cutting }\end{array}$ & & $x$ & & $\mathrm{X}$ & & & $\begin{array}{l}\text { Biocides, metals, surfactant, } \\
\text { viscosifiers }\end{array}$ \\
\hline Produced water & & $x$ & & $X$ & & & $\begin{array}{l}\text { Hydrocarbons, heavy metals, } \\
\text { organic, ammonia, } \mathrm{H}_{2} \mathrm{~S}, \mathrm{BTEX}\end{array}$ \\
\hline Produced sand & & & & $\mathrm{X}$ & & & Hydrocarbons, heavy metals \\
\hline $\begin{array}{l}\text { Oil sludge/bottom } \\
\text { wastes }\end{array}$ & & & & $\mathrm{x}$ & & $\mathrm{X}$ & $\begin{array}{l}\text { Hydrocarbons, heavy metals, } \\
\text { chemicals }\end{array}$ \\
\hline
\end{tabular}

Table 1: Common wastes in $\mathrm{E}$ and $\mathrm{P}$ operations.

*Corresponding author: Helmy Q, Bioscience and Biotechnology Research Center, Institute Teknologi Bandung Ganesha No. 10, Bandung, West Java, Indonesia, E-mail: helmy@tl.itb.ac.id

Received June 04, 2015; Accepted July 15, 2015; Published July 25, 2015

Citation: Helmy Q, Kardena E (2015) Petroleum Oil and Gas Industry Waste Treatment; Common Practice in Indonesia. J Pet Environ Biotechnol 6: 241. doi:10.4172/2157-7463.1000241

Copyright: @ 2015 Helmy Q, et al. This is an open-access article distributed under the terms of the Creative Commons Attribution License, which permits unrestricted use, distribution, and reproduction in any medium, provided the original author and source are credited. 
Citation: Helmy Q, Kardena E (2015) Petroleum Oil and Gas Industry Waste Treatment; Common Practice in Indonesia. J Pet Environ Biotechnol 6: 241. doi:10.4172/2157-7463.1000241

Page 2 of 7

in the past. As a comparison of a large amount of oily waste generated in the $\mathrm{E}$ and $\mathrm{P}$ operation, Chevron Pacific Indonesia/CPI as the biggest oil producer in Indonesia (contributed for up to $40 \%$ national oil production) currently operates nine treatment facility with a combined capacity of 42.000 cubic meters of contaminated soil per treatment cycle and has successfully treated more than half a million cubic meters of contaminated soil from Sumatera Operation Area during 2003 to $2011[5]$

Another $\mathrm{E}$ and $\mathrm{P}$ waste generation with large quantities is produced water. Produced water is any water that is present in a reservoir with the hydrocarbon resource and is produced to the surface with the crude oil or natural gas. This water is frequently referred to as "connate water" or "formation water" and becomes produced water when the reservoir is produced and these fluids are brought to the surface [6]. The ratio of this produced water to produced oil increases over the lifetime of a well. It is common that oil well production fluids in the old reservoirs are eventually composed of $90 \%$ or more of water and only $10 \%$ or less of hydrocarbons [7]. The volume of produced water from oil and gas wells does not remain constant over time. Wells elsewhere in the world average 3 barrel of water for each barrel of oil [8]. The volume of produced water is estimated at more than 8 million barrels per day considering 90 percent of Indonesian oil production is produced from oil wells that have been outstanding for more than 30 years.

This paper will focused on the common treatment practice of crude oil and/or oily sludge contaminated soil and produced water; report both treatment results from lab scale to full scale application in Indonesia.

\section{Waste Treatment}

\section{Oil contaminated soil}

Due to its simplicity, on-site pits have been used for the management of drilling mud/solids, work over/completion fluids, evaporation and storage of produced water, emergency containment of produced fluids, bottom sludge holding pits, oil contaminated soil from abandoned wildcat wells, etc. Burial of these wastes in pits at drilling and production sites has been a popular means of waste disposal in the past (Figure 1). However, with current strong awareness of contaminant migration pathways, the risk associated with burial of waste should become a serious concern.

The severity of the contamination depends on the type of oil involved. Lighter oil has a tendency to seep through the top soil and continues to move quickly through the layers of soil, while heavier oil

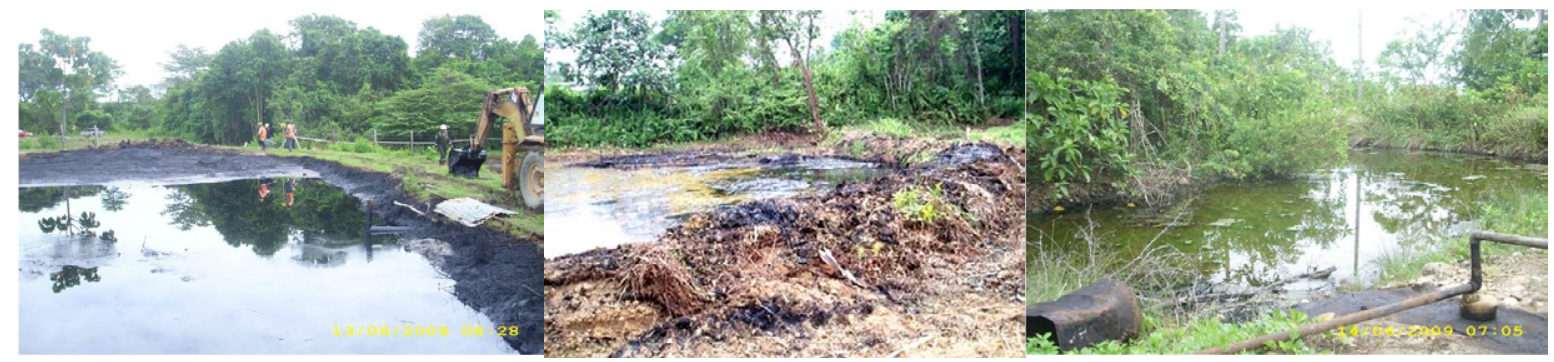

Figure 1: Untreated oily waste from abandoned sludge pit (left), rising oily waste originally from oil sludge burial site (middle), and abandoned drilling pits (right). (author's project documentation with permission from LAPI-ITB Consultant).
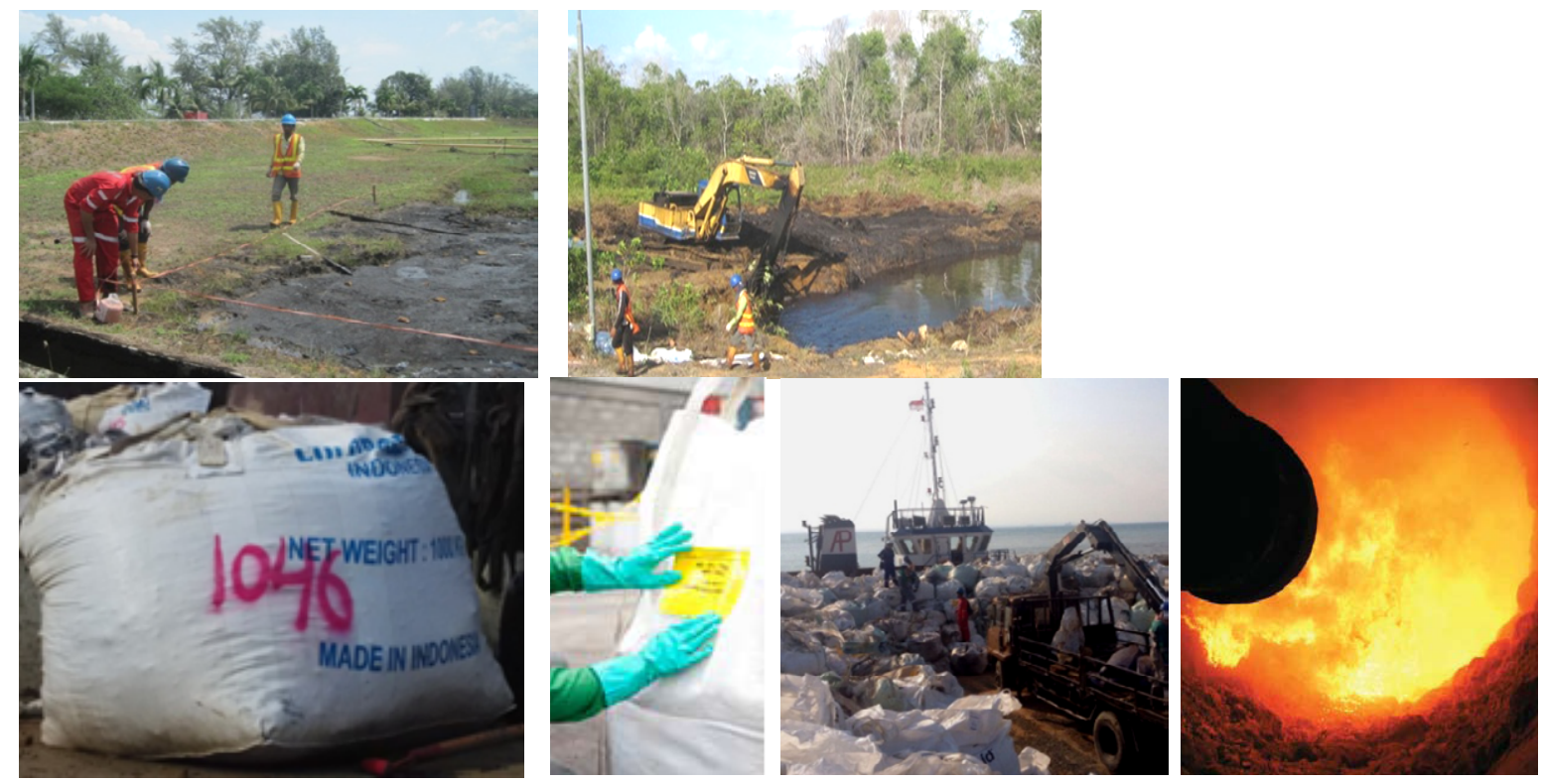

Figure 2: Co-processing of oily sludge activities from (upper left to lower right) site characterization-excavation-containment-labelling-transportation-and thermal destruction in cement kiln. (author's project documentation with permission from LAPI-ITB Consultant). 


\begin{tabular}{|l|c|c|c|}
\hline \multicolumn{1}{|c|}{ Parameter } & OS & OCS & Standard $^{*}$ \\
\hline Density, g/l & 878.8 & 1024.5 & - \\
\hline Viscosity, cp & 450 & - & - \\
\hline TPH content, \% & $30-33$ & $20-22$ & 1 \\
\hline Water content, \% & 2.61 & 4.50 & - \\
\hline Solid content, \% & 35.63 & 73.8 & - \\
\hline Volatile hydrocarbon, \% & 7.65 & 14.4 & - \\
\hline Non-volatile hydrocarbon, \% & 54.61 & 9.5 & - \\
\hline Organic-C (dry weight), \% & 28.49 & - & - \\
\hline As, mg/l & 0.0002 & 0.57 & 5 \\
\hline Ba, mg/l & 0.429 & 1.37 & 100 \\
\hline B, mg/l & 0.011 & - & 500 \\
\hline Cd, mg/l & $<0.001$ & 0.03 & 1 \\
\hline $\mathrm{Cr}, \mathrm{mg} / \mathrm{l}$ & $<0.001$ & $<0.005$ & 5 \\
\hline $\mathrm{Cu}, \mathrm{mg} / \mathrm{l}$ & $<0.001$ & 0.01 & 10 \\
\hline $\mathrm{Pb}, \mathrm{mg} / \mathrm{l}$ & $<0.001$ & $<0.004$ & 5 \\
\hline $\mathrm{Hg}, \mathrm{mg} / \mathrm{l}$ & 0.00132 & 0.12 & 0.2 \\
\hline $\mathrm{Se}, \mathrm{mg} / \mathrm{l}$ & 0.0008 & - & 1 \\
\hline $\mathrm{Ag}, \mathrm{mg} / \mathrm{l}$ & $<0.001$ & - & 5 \\
\hline $\mathrm{Zn}, \mathrm{mg} / \mathrm{l}$ & 0.124 & 0.06 & 50 \\
\hline
\end{tabular}

*Indonesian Ministry of Environment Regulation (MER) No. 128/2003.

Table 2: The characteristics of oil sludge and oil contaminated soil.

\begin{tabular}{|c|c|c|c|}
\hline \multirow[b]{2}{*}{ Time (days) } & \multicolumn{3}{|c|}{ TPH content (\%) } \\
\hline & Control & $\begin{array}{l}\text { Using Bio- } \\
\text { emulsifier }\end{array}$ & Using Tween80 \\
\hline \multicolumn{4}{|l|}{ Soil washing: } \\
\hline 0 & 32.00 & 32.00 & 32.00 \\
\hline 1 & 29.40 & 20.20 & 24.00 \\
\hline Removal Efficiency (\%) & 8.10 & 36.90 & 25.00 \\
\hline \multicolumn{4}{|l|}{ Bioremediation: } \\
\hline 2 & 29.40 & 20.20 & 24.00 \\
\hline 4 & 27.04 & 15.84 & 19.70 \\
\hline 7 & 26.40 & 12.10 & 16.45 \\
\hline 15 & 24.20 & 9.60 & 12.58 \\
\hline 21 & 21.77 & 4.05 & 9.84 \\
\hline 30 & 17.31 & 2.96 & 6.66 \\
\hline Removal efficiency (\%) & 41.10 & 85.30 & 72.30 \\
\hline Total efficiency (\%) & 45.90 & 90.80 & 79.20 \\
\hline
\end{tabular}

Table 3: TPH content the oil sludge after 24 hours soil washing and 30 days bioremediation.

will do opposite. The faster the cleanup operator responds to the spill/ leak, the better the chance of stopping the contamination to spread surrounding. Common practice for oil sludge or oily waste treatment is physical/chemical extraction, centrifugations to recover oil while the remaining residue also oil contaminated soil is treat by mean bioremediation and co-processing method.

Co-processing - In principle, co-processing is incineration which utilizes heat to eliminate waste. The fundamental difference, incineration is generally only reaches a temperature of $800^{\circ} \mathrm{C}$ which still generate waste (bottom ash) and must be managed further in accordance with the applicable regulations. In other hand, the use of oily waste as a fuel blending option to replace fuel otherwise needed to fire the kiln in a cement industry is call co-processing method. The retention time and working temperature that reach $1,500^{\circ} \mathrm{C}$ within a cement kiln are adequate to achieve thermal destruction of contaminants. Cement kiln also have pollution control devices to minimize air emissions from the burning process. The rest of the bottom ash in the process of co-processing is very small and immediately incorporated into the cement products (Figure 2). The concentration of contaminants due to co-processing is very small (trace elements) to make cement product remains safe to use. Other differences, incineration are classified as a form of disposal as for co-processing including recovery efforts. Utilization of hazardous and toxic waste by mean of $3 \mathrm{R}$ (reuse, recycle, recovery) concept is regulated by Indonesian Ministry of Environment Regulation No.2/2008.

Bioremediation - Biological clean up processes is currently in vogue as a promising cost-effective and performance-effective technology to address numerous environmental pollution problems. One of the effective and environmental friendly methods used in oily sludge management is using the biological agents such as petroleum hydrocarbon degrading microbes which are known as bioremediation process method. Our previous work [9-14] reported study on the removal process of oil contaminated soil from various contaminated site in Indonesia.

General characteristics of oil sludge (OS) and oil contaminated soil (OCS) are described in Table 2. Physically, OS form as sticky mud and have viscosity of 450 centipoises. The hydrocarbon compound contains in that OS are dominated by the long carbon chain carbons, i.e. from $\mathrm{C} 11$ up to $\mathrm{C} 44$. It can be concluded that the organic phase of the oil sludge tend to have heavy petroleum residue property. While OCS basically is soil or sand contaminated with petroleum oil or its derivative.

OS was collected from Balongan Oil Refinery Unit, Cirebon and OCS from Bula Oil Field, Seram Indonesia [15].

Common method in the treatment of oily sludge in Indonesia is landfarming bioremediation. But, due to the environmental regulation for applying this method, the maximum content of total petroleum hydrocarbon (TPH) in oily sludge should be $15 \%$ (w/w). So, the TPH content must be reduced to around that level before the bioremediation method can be applied. Reducing the TPH content from the oily sludge can be done i.e. by means of so called soil washing using the addition of emulsifier, either synthetic or bio- products. The bioremediation process itself will also be enhanced or speed up by the addition of these substances.

Table 3 shows laboratory data when oily sludge contaminated soil with high oil content ( $320 \mathrm{~g} \mathrm{TPH} / \mathrm{kg}$ soil) were treated with soil washing method first to reduce oil content before continued with biodegradation process. Microcosm-1 was washed with tap water, microcosm-2 with biosurfactant from Azotobacter sp. at 10 fold CMC (critical micelle concentration) value, and microcosm-3 with Tween 80 also at 10 fold CMC value. Significant TPH reduction was found in microcosm-2 with $37 \%$ reduction efficiency followed with microcosm-3 and -1 with $25 \%$ and $8 \%$ reduction, respectively. Recovered oil were removed from the microcosm reactors and then continued with biodegradation process for 30 days. At the end of the treatment, TPH reduction in the microcosm reactor was measured with highest removal efficiency found at microcosm-2 (85\%) followed with microcosm-3 and -1 with $79 \%$ and $46 \%$ reduction, respectively. The profile of petrofilic microbe growth during bioremediation process is shown in Figure 3.

A significant growth of petrofilic microbe occurred in the 
Citation: Helmy Q, Kardena E (2015) Petroleum Oil and Gas Industry Waste Treatment; Common Practice in Indonesia. J Pet Environ Biotechnol 6: 241. doi:10.4172/2157-7463.1000241

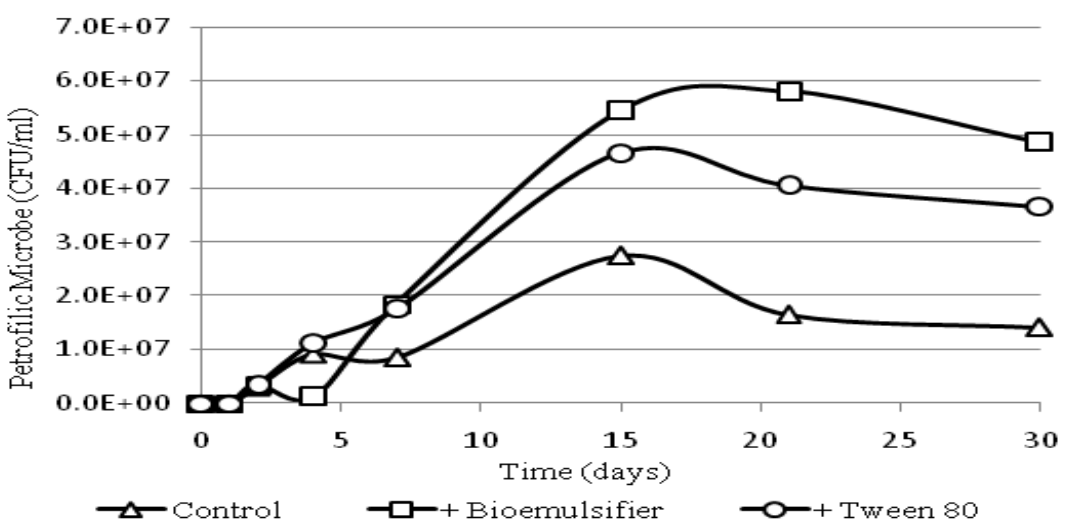

Figure 3: The profile of bacterial growth during bioremediation process

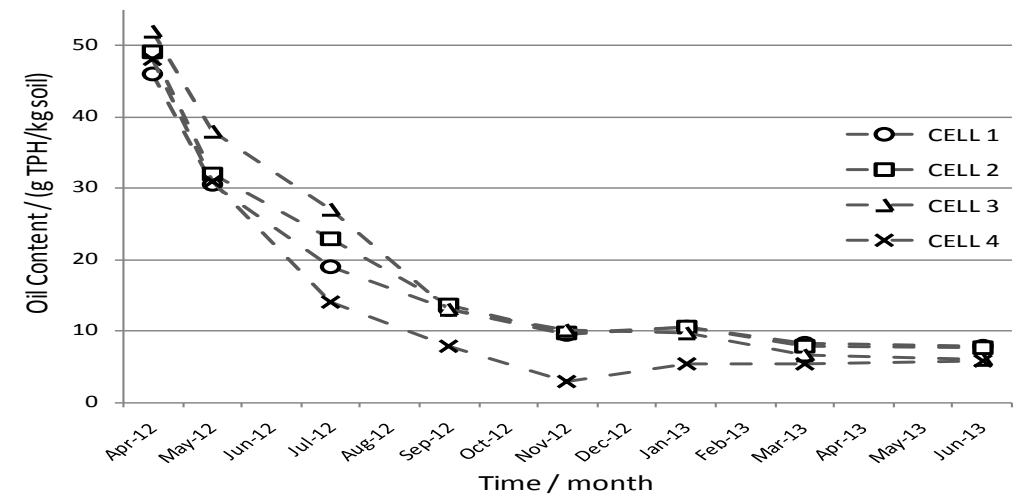

Figure 4: Performance of field application of oil sludge contaminated soil bioremediation process with average initial oil content of $48.7 \mathrm{~g}$ TPH per kg soil from total $4,883 \mathrm{~m}^{3}$ of contaminated soil treated.

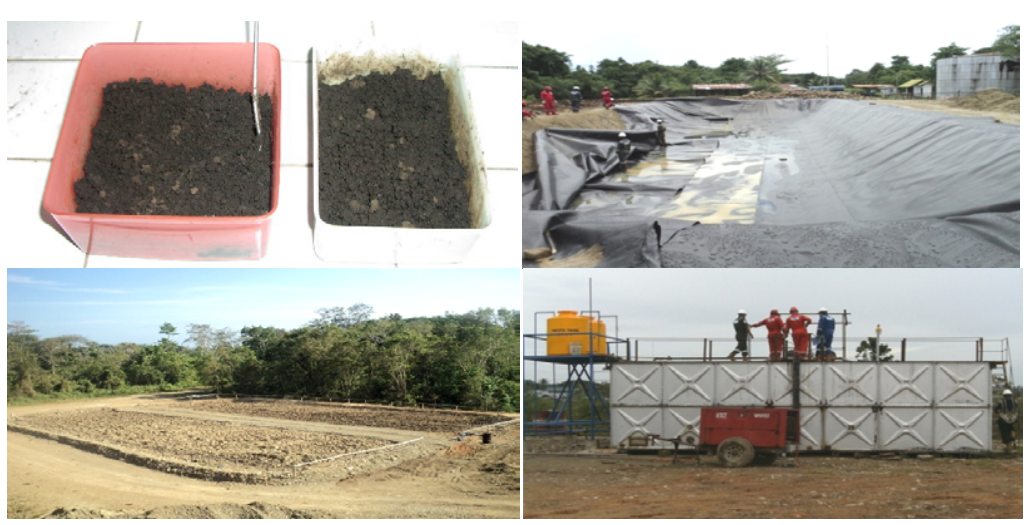

Figure 5: Bioremediation method of oily sludge contaminated soil from lab scale microcosm (upper left) to field scale application i.e. geomembrane lining process (upper right); typical bioremediation cell (lower left); augmented microbe seeding tank (lower right).

bioremediation system supplemented with both emulsifiers (bio and synthetic emulsifier) also without addition of emulsifier as control. This positive result suggests that bio-augmented bacteria could degrade TPH significantly. Bio-augmentation also can be used to increase the biodegradative capabilities of the indigenous microbial population. Non biological degradation (physical transformation) also occurred in the process; however the biological transformation dominated the process based on the growth of bacteria observed during the process.
Field scale of the bioremediation project showed that addition of both specific degrader microbe and biosurfactants producing bacteria are succeed in removing $46 \mathrm{~g}$ total petroleum hydrocarbon per $\mathrm{kg}$ soil from $4,883 \mathrm{~m}^{3}$ of oil sludge contaminated soil during 16 months of treatment (Figures 4 and 5).

Hydrocarbon contaminants e.g. oily sludge, oil contaminated soil are removed from the environment, primarily as a result of their biodegradation, which is performed by native microbial populations. 
Such biodegradation is known to be time-consuming and new technologies have been developed; for example the addition of surfactant help to stimulate the indigenous microbial population to degrade hydrocarbons at rates higher than those which could be achieved through addition of nutrients alone [11].

\section{Produced water}

Large quantities of water are produced along with hydrocarbons in oil and gas fields all over the world. Water production quantities continue to increase as the oil and gas fields reach maturity. Produced water comes as a by-product of petroleum production and requires to be managed efficiently.

A great deal of scientific research has been carried out to determine the consequences of long-term exposure of produced water on the environment. Some of this research has given alarming results. It is reported that some of the toxic components in produced water may cause irreversible damage to the surrounding environment. Because of this potential risk, enormous efforts are being made by oil companies operating in Indonesia in developing techniques for managing produced water. Remaining oil in treated and discharged produced water is the principal source for hydrocarbon discharges from the oil companies to the environment.

Recently, Indonesian government has changed the regulation on produced water quality standard. The new standard refer to the terminal based, meaning that although the crude oil is explored off shore, if then the process of purifying the crude oil is carried out on shore then the

\begin{tabular}{|c|c|c|c|c|c|}
\hline \multirow{2}{*}{ Parameter } & \multirow{2}{*}{ Unit } & \multicolumn{3}{|c|}{ Samples Location } & \multirow{2}{*}{ Standard $^{*}$} \\
\cline { 2 - 6 } & & $\mathbf{1}$ & $\mathbf{2}$ & $\mathbf{3}$ & \\
\hline TDS & $\mathrm{ppm}$ & 12.900 & 1.144 & - & 4.000 \\
\hline $\mathrm{pH}$ & - & 6.77 & $5-9$ & 8 & $6-9$ \\
\hline COD & $\mathrm{ppm}$ & 3.000 & 580 & 1.872 & 200 \\
\hline Nitrate & $\mathrm{ppm}$ & 0.189 & 1.2 & - & - \\
\hline Nitrite & $\mathrm{ppm}$ & 0.011 & 0.11 & - & - \\
\hline Ammonia & $\mathrm{ppm}$ & 14.11 & 48 & 0.22 & 5 \\
\hline $\begin{array}{c}\text { Oil and } \\
\text { Grease }\end{array}$ & $\mathrm{ppm}$ & 28 & 24 & 931 & 25 \\
\hline Phenol & $\mathrm{ppm}$ & 104.6 & 2.6 & 0.03 & 2 \\
\hline Phosphate & $\mathrm{ppm}$ & 0.072 & 0.136 & - & - \\
\hline Benzene & $\mathrm{ppm}$ & - & - & 0.08 & - \\
\hline Toluene & $\mathrm{ppm}$ & - & - & 0.37 & - \\
\hline Xylene & $\mathrm{ppm}$ & - & - & 0.93 & - \\
\hline
\end{tabular}

1. CPU-Total E and P Indonesie; 2. Pertamina Refinery Unit IV; 3. Kawengan Oil Field *MER No.19/2010

Table 4: The characteristics of produced water in Indonesia.

\begin{tabular}{|c|c|c|c|}
\hline No & Source & Parameters & Limit \\
\hline \multirow[t]{8}{*}{1} & Produced Water & COD & $200 \mathrm{mg} / \mathrm{l}$ \\
\hline & & Oil and Grease & $25 \mathrm{mg} / \mathrm{l}$ \\
\hline & & Sulfide & $0.5 \mathrm{mg} / \mathrm{l}$ \\
\hline & & Ammonia & $5 \mathrm{mg} / \mathrm{l}$ \\
\hline & & Phenol & $2 \mathrm{mg} / \mathrm{l}$ \\
\hline & & Temperature & $40^{\circ} \mathrm{C}$ \\
\hline & & $\mathrm{pH}$ & $6-9$ \\
\hline & & TDS & $4,000 \mathrm{mg} / \mathrm{l}$ \\
\hline \multirow[t]{2}{*}{2} & Drainage & Oil and Grease & $15 \mathrm{mg} / \mathrm{l}$ \\
\hline & & Total Organic Carbon & $110 \mathrm{mg} / \mathrm{l}$ \\
\hline
\end{tabular}

Table 5: Produced water and drainage standard for oil and gas activity (onshore facility) MER No.19/2010. produced water must comply with on-shore standard. As consequence, parameters such as COD and Phenol which did not consider previously by operators now become a great concern (Table 4 ). Common practice for the treatment of produced water in Indonesia is well injection and processed in a wastewater treatment facility [16].

Well Injection - Injection refers to the pumping down of produced water into suitable formation for disposal. Disposal wells are designed to provide a wellbore to transport liquids into underground reservoirs in a manner that will not adversely affect the environment. The target formation for disposal should be hydro-geologically and mechanically isolated from usable sources of water. This formation also will not contain commercial quantities of oil and gas. CPI as the biggest oil producer in Indonesia reported to inject about 6 million barrels produced water per day in accordance to the enhanced oil recovery technique by water flooding and steam flooding in order to maintain the reservoir pressure also as a waste management practice. Other company, Medco E and P Rimau Asset also reported to inject about 175,000 barrels produced water per day to achieved zero wastewater surface discharge since 2008 [17]. VICO Indonesia also reported to produce 40,000 barrels per day of produce water and being re-injected back to the reservoir since 2004 [18]. Chevron Geothermal Indonesia Darajat Asset and Chevron Geothermal Salak Asset reported to inject about 75,000 and 941,000 barrels produced water per day since 2010, respectively [19].

Produced Water Treatment Facility - The most common practice in use in Indonesia for management of produced water is treatment in gravity based separation equipment and discharge to sea/water body. For a long time the only governmental regulation for produced water discharges in this petroleum sector has been concerning concentration of non-polar oil in water (OIW). Little attention has been given to dissolved organics. There is now wide agreement within the petroleum industry, governments and scientists that focus should now be put on dissolved organic components, and production chemicals (Table 5). The oil content in water shall be as low as possible and the industry shall make use of best available technology (BAT) $[20,21]$.

Produced water treatment has traditionally taken place in gravity based equipment, where the difference in the density of the two liquids to be separated is utilized. Such separation is commonly performed in huge horizontal tanks at different pressures. Flotation of the lighter components (oil) can be enhanced by means of finely distributed gas bubbles going out of solution (pressure reduction) and parallel plate packages installed diagonally in the separation vessel. In order to comply with the regulation regarding organic component and production chemicals, biological process treatment is further applied to the system mainly of activated sludge process e.g.: aerated lagoon, contact stabilization, extended aeration. Recently commissioned wastewater treatment facility was operated by Pertamina Refinery Unit IV, Cilacap to treat about 4,000 cubic meters produced water per day (Figure 6).

Produced water treatment plant performance during commissioning was shown in Table 6 . During 3 month commissioning period, combined physical and biological process are satisfied in removing key parameter required by regulation. Physical process i.e., API, CPI and DAF system are served to remove oil in water and some organics associated with oil removed, while biological process i.e.: activated sludge system is served to removed remaining organic component and production chemicals within produce water.

\section{Conclusion}

Contamination of soils, groundwater, sediments, surface water, 
Citation: Helmy Q, Kardena E (2015) Petroleum Oil and Gas Industry Waste Treatment; Common Practice in Indonesia. J Pet Environ Biotechnol 6: 241. doi:10.4172/2157-7463.1000241

Page 6 of 7

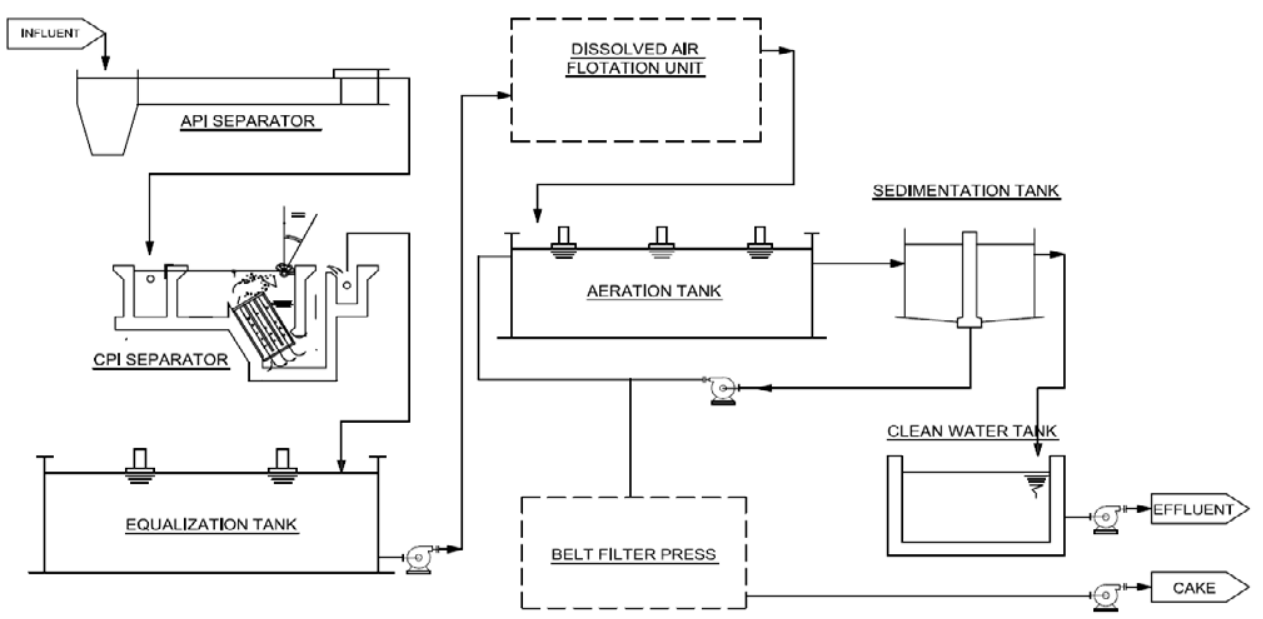

Figure 6: Typical produced water treatment facility.

\begin{tabular}{|c|c|c|c|c|c|c|c|c|}
\hline Parameter & Unit & Inf. & API & CPI & DAF & Eff. & Efficiency, \% & Standard* \\
\hline COD & $\mathrm{mg} / \mathrm{l}$ & 1000 & 800 & 720 & 533.6 & 115.6 & 88.4 & 200 \\
\hline BOD & $\mathrm{mg} / \mathrm{l}$ & 600 & 480 & 432 & - & 58.7 & 90.2 & - \\
\hline Oil Content & $\mathrm{mg} / \mathrm{l}$ & 540 & 300 & 75 & 15 & 12 & 97.8 & 25 \\
\hline Ammonia & $\mathrm{mg} / \mathrm{l}$ & 100 & 100 & 100 & 70 & 4 & 96.0 & 5 \\
\hline Sulfide & $\mathrm{mg} / \mathrm{l}$ & 15 & 15 & 15 & 10.5 & 0.3 & 98.0 & 0.5 \\
\hline Phenol & $\mathrm{mg} / \mathrm{l}$ & 70 & 70 & 70 & 42 & 0.4 & 99.4 & 2 \\
\hline
\end{tabular}

Average from triplicate measurement; "MER No. 19/2010.

Table 6: Produced water treatment plant performance during commissioning

and air with hazardous and toxic chemicals is one of the major problems facing the oil and gas industry in Indonesia. Recent accidents attribute to oil spillages in Tarakan (East Kalimantan), Sorong (Papua), Indramayu (West Java), Bojonegoro (East Java), and Cilacap (Central Java) should giving a due consideration of the national level. Effective and responsible waste handling and disposal are key parameters of an organization's environmental management system. E and $\mathrm{P}$ waste generation are important to be properly managed in order to minimize their potential harm to health and environment also an efficient management of those waste can reduce operating costs and potential liabilities. Disposal options in some areas may be restricted by lack of established waste management facilities and infrastructure. However, the oil and gas operator may find it necessary to construct and manage the necessary facilities. Although this approach may be expensive in the short term, it can often minimize long term liabilities.

\section{Acknowledgment}

Authors gratefully thanks to colleagues in their support/permission and providing some data i.e.: LAPI-ITB Consultant, Dr. Rudy Laksmono, Basdedi Tua Siahaan, and Yessi Gardenia for providing project's documentation.

\section{References}

1. BP (2015) BP Energy Outlook 2035. London, United Kingdom.

2. MEMR (2014) Handbook of Energy and Economic Statistic of Indonesia. Center for Data and Information Technology on Energy and Mineral resources. Ministry of Energy and Mineral Resources Republic of Indonesia.

3. Lima CS, Lima RO, Silva EFB, Castro KKV, Chiavone FO, et al. (2014) Analysis of Petroleum Oily Sludge Produced from Oil-Water Separator. Rev. Virtual Quim 6: 1160-1171.

4. Bishop JM (1991) Applied Oceanography. Federal Emergency Management Agency and Department of Civil Engineering. Catholic University of America.

5. CPI (2012) Chevron Pacific Indonesia, Bioremediation Program. Fact SheetPolicy, Government and Public Affairs Dept. Indonesia.
6. Veil JA, Puder MG, Elcock D, Redweik RJ (2004) White Paper Describing Produced Water from Production of Crude Oil, Natural Gas, and Coal Bed Methane. National Energy Technology Laboratory. U.S. Department of Energy.

7. Desrina R (2012) Effect of Chemicals on the Formation of Tar Balls from Overboard Water Discharges-An Analysis of Environmental View. Scientific Contributions Oil and Gas 35: 91-98.

8. Khatib Z, Verbeek P (2003) Water to Value-Produced Water Management for Sustainable Field Development of Mature and Green Fields. Journal of Petroleum Technology.

9. Helmy Q, Suryatmana P, Kardena E, Funamizu NW (2008) Biosurfactants Production from Azotobacter sp. and its Application in Biodegradation of Petroleum Hydrocarbon. Journal of Applied and Industrial Biotechnology in Tropical Region.

10. Helmy Q, Kardena EW (2009) Performance of Petrofilic Consortia and Effect of Surfactant Tween 80 Addition in the Oil Sludge Removal Process. Journal of Applied Sciences in Environmental Sanitation 4: 207-218.

11. Helmy Q, Kardena E, Nurachman Z, dan Wisjnuprapto (2010) Application of Biosurfactant Produced by Azotobacter vinelandii AV01 for Enhanced Oil Recovery and Biodegradation of Oil Sludge. International Journal of Civil \& Environmental Engineering IJCEE 10: 7-14.

12. Helmy Q, Kardena E, Funamizu N, dan Wisjnuprapto (2011) Strategies toward Commercial Scale of Biosurfactant Production as Potential Substitute for Its Chemically Counterparts. International Journal of Biotechnology 12: 66-86.

13. Helmy Q, Laksmono R, Kardena E (2015) Bioremediation of Aged Petroleum Oil Contaminated Soil: from Laboratory Scale to Full Scale Application. Procedia Chemistry 14: 326-333.

14. Kardena E, Helmy Q, Funamizu N (2015) Biosurfactant and Soil Bioremediation. Book Chapter in Biosurfactants: Production and Utilization-Processes Technologies, and Economics. CRC Press-Taylor and Francis Group pp: 327-379.

15. MER (2003) Procedure and Technical Requirements of Oil Contaminated Soil by Biological Process. Indonesian Ministry of Environment.

16. MER (2010) Wastewater Quality Standards for Oil and Gas and Geotherma Activity/ Industry. Indonesian Ministry of Environment Regulation No. 19/2010 
Citation: Helmy Q, Kardena E (2015) Petroleum Oil and Gas Industry Waste Treatment; Common Practice in Indonesia. J Pet Environ Biotechnol 6: 241. doi:10.4172/2157-7463.1000241

Page 7 of 7

17. Medco (2014) Summary Document Performance on Environmental ManagementMedco E and P Rimau Asset, Ministry of Environment, Indonesia.

18. VICO (2005) Environmental Statement. VICO Indonesia.

19. CGI (2013) Summary Document Performance on Environmental ManagementChevron Geothermal Indonesia Darajat Asset, Ministry of Environment, Indonesia.
20. MER (2008) Utilization of Hazardous and Toxic Waste. Indonesian Ministry of Environment.

21. Owens CK, Rycroft DR, Stephenson MT, Norris G, Johnson JA, et al. (1993) Exploration and Production ( $E$ and $P$ ) Waste Management Guidelines. The $E$ and P Forum Report No. 2.58/196. London, United Kingdom. 